\title{
Comparative Analysis of Agricultural Incomes from Organic and Conventional Farming Systems in North Benin: Case of the Municipality of Tanguieta
}

\author{
Paul S. Hountondji \\ Silvère D. Tovignan \\ Ricardo L. Hountondji \\ Haroll Kokoye
}

Faculty of Agronomy, University of Parakou, Republic of Benin

Christian S. Adjiba

Laboratory of Analysis and Research on Economic and Social Dynamics

(LARDES), Department of Rural Economics and Sociology, Benin

Régina D. Bonouzin

Stanislas A. Koussahoue

Fanyiou Jonas

Faculty of Agronomy, University of Parakou, Republic of Benin

\section{Doi:10.19044/esj.2021.v17n14p85}

Submitted: 31 December 2020

Accepted: 04 March 2021

Published: 30 April 2021
Copyright 2021 Author(s)

Under Creative Commons BY-NC-ND

4.0 OPEN ACCESS

Cite As:

Hountondji P.S., Tovignan S.D., Hountondji R.L., Kokoye H., Adjiba C.S., Bonouzin R.D., Koussahoue S.A. \& Jonas F. (2021). Comparative Analysis of Agricultural Incomes from Organic and Conventional Farming Systems in North Benin: Case of the Municipality of Tanguieta. European Scientific Journal, ESJ, 17(14), 85.

https://doi.org/10.19044/esj.2021.v17n14p85

\section{Abstract}

It is likely that Goals 2, 14, and 15 of the Sustainable Development Goals (SDGs) will never be achieved if organic farming remains economically less profitable than conventional farming. This study was aimed at making a comparative analysis of the economic performance of organic and conventional farming systems. The data were collected from 36 organic and 39 conventional farmers, by individual interviews using semi-structured questionnaires. Descriptive, economic performance indicators and ordinary least square (OLS) regression analysis were used. The results show that the cotton farming activity remains economically more profitable in organic systems, despite the technical constraints of farming. In combination with 
cotton, corn and soybeans are more profitable in organic systems than conventional. Moreover, level of prosperity, distance from home to cotton farms are positively related to conventional farming system income at $1 \%$ and 5\% level of significance. Agricultural assets, contact with extension agents, experience in organic farming, secondary activity is positively related to organic system income at $1 \%, 5 \%$, and 5\% level of significance; whilst the household size and the cotton acreage are negatively related to organic system income at $1 \%$ and $5 \%$ level of significance. It would then be necessary to continue and intensify the programs of diffusion of the best organic cultivation practices to the farmers whatever their experience in organic and to be more interested in corn and soy crops.

Keywords: Farming, Farm gross income, Organic, Conventional, Tanguieta

\section{Introduction}

The cotton sector represents the basis of the rural economy in Benin. It contributes to the formation of the GDP to the tune of $13 \%$ and about $70 \%$ of the total value of exports and 35\% of tax revenues (excluding customs) (Ton $\&$ Wankpo, 2004). In Benin, the socio-economic role played by cotton is very considerable, being a source of employment and a generator of income for most farms (Degla, 2012; Dossa et al., 2018; Hermann et al., 2016).

Despite the enormous efforts made by the Government and its partners for its development, this sector has been facing several difficulties in recent years. Indeed, in addition to fluctuations in global costs, other increasingly persistent internal handicaps have led to a drastic drop in farming in recent years. These include, in particular the decline in soil fertility, climatic hazards, phytosanitary problems, insufficient technical supervision for farmers, and dysfunctions within professional families operating in the sector (OBEPAB, 2002; Ton \& Wankpo, 2004). Three farming systems can be identified in the cotton sector, namely conventional cotton, organic cotton, and cotton with established targeted control. The first two are the most important with a preponderance of conventional cotton (Matthess et al., 2005). Organic cotton excludes the use of any chemicals for soil fertility management and pest control. In terms of cultivation practices, the organic system presents specificities that can constitute a threat or an opportunity for the financial and social profitability of the activity. Organic cotton farming has benefits for the farmer and for the nation. In practice, it does not use chemical fertilizers and pesticides; fertilization is provided through crop rotation, use of potting soil, waste palm oil, animal manure, and weeds (Houndekon, 2013). Many questions have always been asked about the economic benefit of organic farming, although organic farming offers many benefits to agricultural farmers, the environment, and human health. It can even be said that the most 
economically advantageous agriculture between organic and conventional agriculture depends on the region where the farming takes place and on the control of cultivation practices by the farmers themselves. Because, when some authors have favorable arguments for organic farming from an economic, technical, and even ecological point of view (Eyhorn et al., 2011; Krause \& Machek, 2018; Tovignan et al., 2018), many other authors argue that it is rather conventional agriculture that offers the most economic benefits (Brookes \& Barfoot, 2012; Finger et al., 2011; Forster et al., 2013). It is even noted that organic farming continues to come up against technical constraints relating to the poor organization and exploitation of farming techniques. The area of this study is no exception. Organic farmers' experience farming-related difficulties, particularly in the mobilization of agricultural inputs (organic manure and fertilizers). Farmers of the organic system sow in small areas compared to those of the other system (Danus, 2020); and they do not easily spread their organic fertilizers over large areas. At this rate, one wonders if the farming of the organic farming system is more profitable than the conventional one in this area. Moreover, if this is not the case, SDGs 2, 14, and 15 will probably never be achieved. It would then be important to carry out investigations in this study area. Most of the studies conducted in the cotton sector were related to the economic and financial profitability of organic and conventional cotton cultivation and the comparative analyzes of the economic performance of the two systems (Degla, 2012; Dossa et al., 2018; Finger et al., 2011; Forster et al., 2013; Houndekon, 2013; Krause \& Machek, 2018; Paraïso et al., 2012; Tovignan et al., 2018; Vognan et al., 2017). Some of these studies have shown that organic agriculture is more economically profitable than conventional agriculture (Houndekon, 2013; Tovignan et al., 2018), while others have shown the opposite (Finger et al., 2011; Forster et al., 2013). It has been shown that yields from organic farming will gradually increase and improve as farmers master the new technology (Houndekon, 2013). It would seem then that experience in organic farming is a very important factor in improving economic results.

In general, in Benin, studies comparing the two systems show several shortcomings. This concerns, for example, the failure to take into account the number of years of adoption of organic farming in the choice of the farmers surveyed; failure to consider other crops associated with organic and conventional cotton. This study was carried out taking into account the experience of organic farmers and other crops in the farming system in rotation with cotton. It expands the literature on:

- the comparative analysis between the two farming systems (conventional and organic) by making it possible to know whether the organic farmers experienced in organic farming have higher economic performance or not than those in conventional farming; 
- crops that offer better economic performance in association with organic and conventional cotton.

- It will then make it possible to orient agricultural policies in the direction of promoting organic farming in general and the choice of crops to be combined with cotton.

\section{Materials and Methods}

\section{Presentation of the study area: Municipality of Tanguieta}

The commune of Tanguieta is located in the north-west of the department of Atacora and covers an area of 5,456 km2. Included between 10 $\circ 37$ 'and $11^{\circ} 46^{\prime}$ North Latitude and $01^{\circ} 07$ 'and $02^{\circ}$ East longitude, it is limited to the North by the Pendjari, to the South by the municipalities of Toucountouna and Boukoumbé, to the West by the municipalities of Materiel and Cobly and in the East by the municipalities of Kérou and kouandé. The municipality brings together 39 villages or city districts spread over five (5) districts. The climate is of the Sudano-Sahelian continental type with a rainy season that goes from May to November and a dry season that lasts around four months (from November to May). The temperature varies throughout the year between $15^{\circ} \mathrm{C}$ and $35^{\circ} \mathrm{C}$. Rainfall is abundant in August and September, with rainfall ranging from $800 \mathrm{~mm}$ to $1100 \mathrm{~mm}$.

\section{Study sampling}

\section{Selection of the study village and heads of household}

The criteria for choosing the village are: the presence of organic farming (certified) and its year of introduction (at least 4 years), physical accessibility in any season of the year and the number of households practicing organic or conventional cotton, the difficulties encountered by farmers are technical (organic fertilizers and farming practices). Thus, discussions with extension agents and research enabled the selection of the village of Batia in the commune of Tanguieta. The unit of observation in the case of this study is the head of household producing organic or conventional cotton. The random sampling technique was used for the selection of households to be sampled. Thus, the census of all cotton-producing households was carried out in each village. Thanks to the exhaustive list of identifying households, an overall sampling rate of $31 \%$ was applied. Thus, 75 heads of household were surveyed: 36 organic cotton farmers and 39 conventional cotton farmers.

\section{Types of data collection and data collection method}

For the verification of the research hypotheses, the following data were collected: 
The socioeconomic and demographic characteristics of the farmers: gender, age, level of education, literacy, household size, number of agricultural workers, number of years of experience in organic farming, etc.

Crop farming (cotton and others): areas sown, cropping history, quantity, and price of inputs (seeds, biopesticides, mineral fertilizers, synthetic chemical pesticides, organic manures, etc.), cropping operations, types and quantity of labor work, the quantity of cotton produced and its selling price. The data were collected via semi-structured questionnaires during individual interviews.

\section{Data analysis}

To analyze the profitability of cotton farming systems, using Excel and SPSS V 21 software, variable farming costs as well as gross margins; gross incomes, gross products were calculated by the type of cotton and for rotation crops, associated with cotton.

\section{Concept of economic performance}

The concept of performance can have a multitude of meanings. It can be linked to notions of effectiveness and efficiency (Sonnentag \& Frese, 2002). It can also be defined as the level of achievement of results in relation to the efforts committed and the resources consumed. This definition emphasizes what one seeks to achieve ultimately and corresponds to the definition given by the OECD: "the performance or results of activities carried out in the context of pursuing objectives. Its purpose is to increase the number of cases in which public authorities achieve their objectives" (OCDE, 2005). Performance is also understood as the ability of a company to achieve its objectives (Grüning, 2002). In this study, the last two definitions will be taken into account; which is, the capacity of companies in terms of achieving their goals. There are several types of performance: financial, social, organizational, societal, and economic. Economic performance is considered in this study and is equated with economic profitability (Gbede et al., 2018). In fact, on farms, from an economic point of view, the objectives pursued are the maximization of profit and the minimization of farming costs (Echaudemaison et al., 2017). Thus, farmers seek to be profitable, and this is how they profit from their activities. Several indicators have been used by several authors on profitability or economic performance: gross and net margins, productivity working averages; benefit-cost ratios, etc. (Degla, 2012; Dossa et al., 2018; Gbede et al., 2018; Paraïso et al., 2012; Tovignan et al., 2018). Two indicators are taken into account in this study: gross margin (MB) and gross income (RB). To assess system margin and gross income, it is important to estimate farming costs in advance. 


\section{Evaluation of farming costs}

The variable costs $(\mathrm{CV})$ of farming vary according to the farming volumes. In the study, they include the costs of inputs (organic manure, biopesticides, mineral fertilizers, chemical pesticides), occasionally hired labor, and other costs (transport, food given to agricultural workers during their service). The variable costs are expressed in FCFA / ha.

\section{Calculation of economic performance indicators}

To assess the economic performance of farmings (organic and conventional farming systems), the gross margin (MB) and gross income (RB) indicators were calculated. The gross margin represents the operator's gain after all current expenses (variable costs) have been covered.

$-\mathrm{MB}=\mathrm{PBV}-\mathrm{CV}$ (Darbelet and Laugine., 1990); MB (FCFA/ha), PBV (FCFA/ha) and CV (FCFA/ha)

The gross product (PBV) corresponds to the yield (Rdt) multiplied by the unit selling price (PU).

-PBV= Rdt*PU (Darbelet and Laugine., 1990); Rdt (FCFA/ha) and PBV (FCFA/ha).

Gross income is the sum of the gross margins of all crops in a farming system of the study.

$\mathrm{RB}=\Sigma \mathrm{MB}$ (gross margins) $\mathrm{i}$; with i representing all the system crops.

\section{Significance test between cotton types and other rotation crops}

In order to compare the costs and performance indicators of the two cotton farming options and the associated crops on each of the farms (conventional versus organic), Student's T-test was carried out with SPSS V 21. This test makes it possible to assess the significance of the differences between the calculated indicators. Student's t law is used to test the statistical significance of the estimated parameters. It comes that:

Hypothesis test

Ho: $\rho=0$ against H1: $\rho \neq 0$ with $\rho=$ correlation coefficient

We calculate: 


$$
\boldsymbol{t}^{*}=\frac{\hat{\boldsymbol{b}}_{\boldsymbol{i}}-\boldsymbol{b}^{*}}{S\left(\hat{b}_{i}\right)} \rightarrow \mathrm{t}(\mathrm{n}-\mathrm{k}) \text {; that is, the Student's t statistic of the }
$$

degree of freedom $n-k$, with $n=$ sample size and $k=$ number of parameters estimated in the regression model (including b0). The software used gives us the value of $t *$ and the probability of significance.

If / $\mathrm{t} * /<\mathrm{t}(\mathrm{n}-\mathrm{k} ; 1-\alpha / 2)$, then we accept H0, If / $\mathrm{t} * />\mathrm{t}(\mathrm{n}-\mathrm{k} ; 1-\alpha / 2)$, then we accept $\mathrm{H} 1$.

With: $-\alpha$ is the significance level. Which is equal to $5 \%$.

$\mathrm{t}(\mathrm{n}-\mathrm{k} ; 1-\alpha / 2)$ is the $\mathrm{t}$ read from the statistical table. The $\mathrm{t}$ read is equal to 1.96 for $\alpha=5 \%$.

\section{Method for estimating the determinants of the economic performance of organic and conventional farms}

To identify the determinants of the economic performance of organic and conventional farms, multiple regressions represented by ordinary least squares (OLS) were employed, because of the continuous nature of the dependent variable "farm income from the farm". This method was used by (Sodjinou et al., 2015; Tovignan et al., 2018) in the analysis of the determinants of the profitability of organic and conventional cotton in Benin.

Therefore, the empirical model of simple regression is of the form:

$$
Y i=\beta X i+\mu i
$$

Where $\mathrm{Yi}$ is the dependent variable (gross income from the organic or conventional system);

$\mathrm{Xi}$ : the vector of the explanatory variables that are the Socio-economic and institutional factors presented in Table 1;

$\mu \mathrm{i}$ : vector of error terms;

$\beta$ : the vector of the parameters to be estimated 
Table 1: Description of the variables introduced into the model to estimate the determinants of both systems

\begin{tabular}{|l|l|l|}
\hline Variables & Measures & $\begin{array}{l}\text { Expected } \\
\text { signs }\end{array}$ \\
\hline Age & Continuous variable & \pm \\
\hline Gender & Binary variable $(1=$ Male, $0=$ Female $)$ & \pm \\
\hline Level of prosperity & Binary variable $(1=$ Prosperous, $0=$ others $)$ & + \\
\hline Primary level & Binary variable $(1=$ Yes, $0=$ no $)$ & + \\
\hline Possession of secondary activity & Binary variable $(1=$ Yes, $0=$ no $)$ & + \\
\hline Access to formal credit & Binary variable $(1=$ Yes, $0=$ no $)$ & \pm \\
\hline Household size & Continuous variable & \pm \\
\hline Agricultural assets & Continuous variable & + \\
\hline Contact with extension agents & Binary variable $(1=$ Yes, $0=$ no $)$ & + \\
\hline Total available acreage & Continuous variable & \pm \\
\hline Cotton acreage & Continuous variable & + \\
\hline $\begin{array}{l}\text { Experience in organic cotton } \\
\text { farming }\end{array}$ & Continuous variable & + \\
\hline Distance home - cotton farm & Continuous variable & \pm \\
\hline
\end{tabular}

\section{Results}

\section{Socio-economic and demographic characteristics of households}

\section{Gender and age of heads of household}

Figure 1 shows the distribution by gender of the heads of household in the different types of farms. Men (57.57\% against $41.93 \%$ of women) head the majority of households surveyed. Women are more represented on organic farms than men $(67.74 \%$ of households surveyed in this option are headed by women). The low representativeness of women on conventional farms (i.e. $16.12 \%$ ) compared to organic ones can be explained by the fact that in conventional farming, women very often depend on men for the acquisition of inputs and the marketing of cotton., while in the organic, women are more autonomous in the management of their farms. The average ages of the heads of household of the different types of conventional and organic farms are 40 $( \pm 12.18)$ and $43.8( \pm 13.25)$ years respectively (Table $\left.\mathrm{N}^{\circ} 2\right)$. 


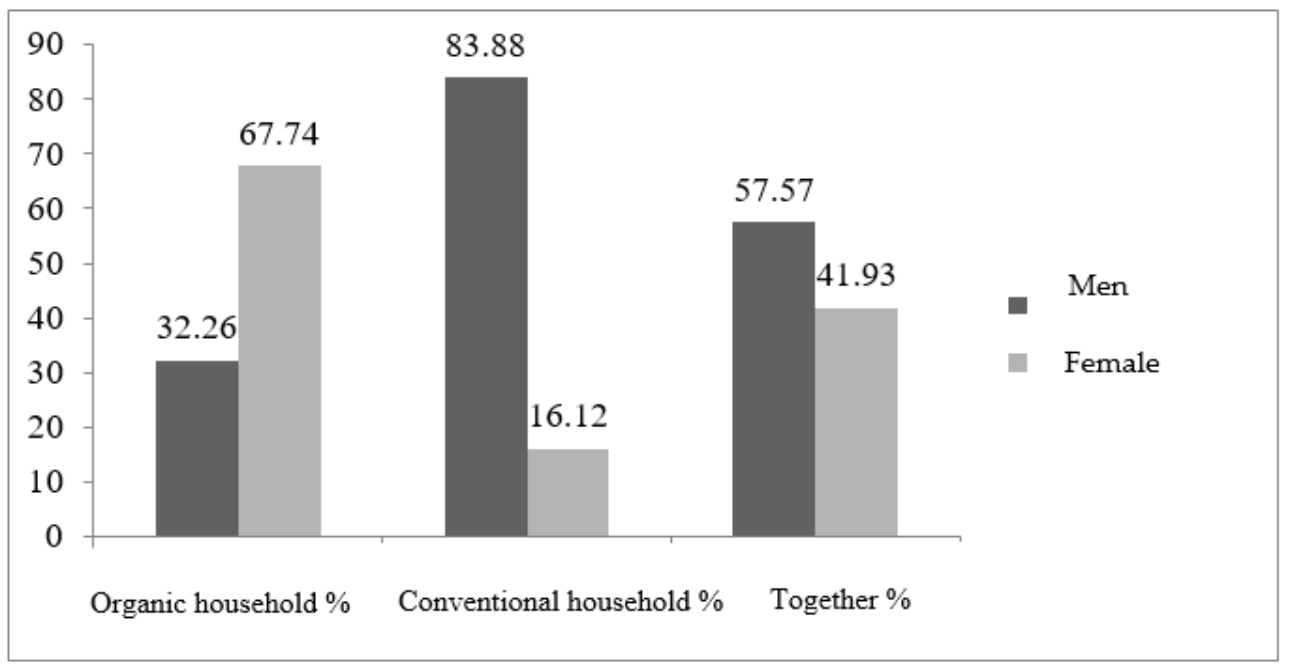

Figure 1: Distribution by gender of heads of households according to cotton types

\section{Educational attainment and literacy}

Table 2 indicates that the average level of education of heads of household is $2.35( \pm 2.98)$ and $0.77( \pm 2.15)$ years for households of conventional and organic types, respectively. The difference between these two means is significant at the $1 \%$ level. Furthermore, overall, only $29.04 \%$ of the heads of households surveyed are educated and $8.07 \%$ are literate (Figure $\mathrm{N}^{\circ}$ 2). The percentages of educated and literate heads of household are higher within conventional households.

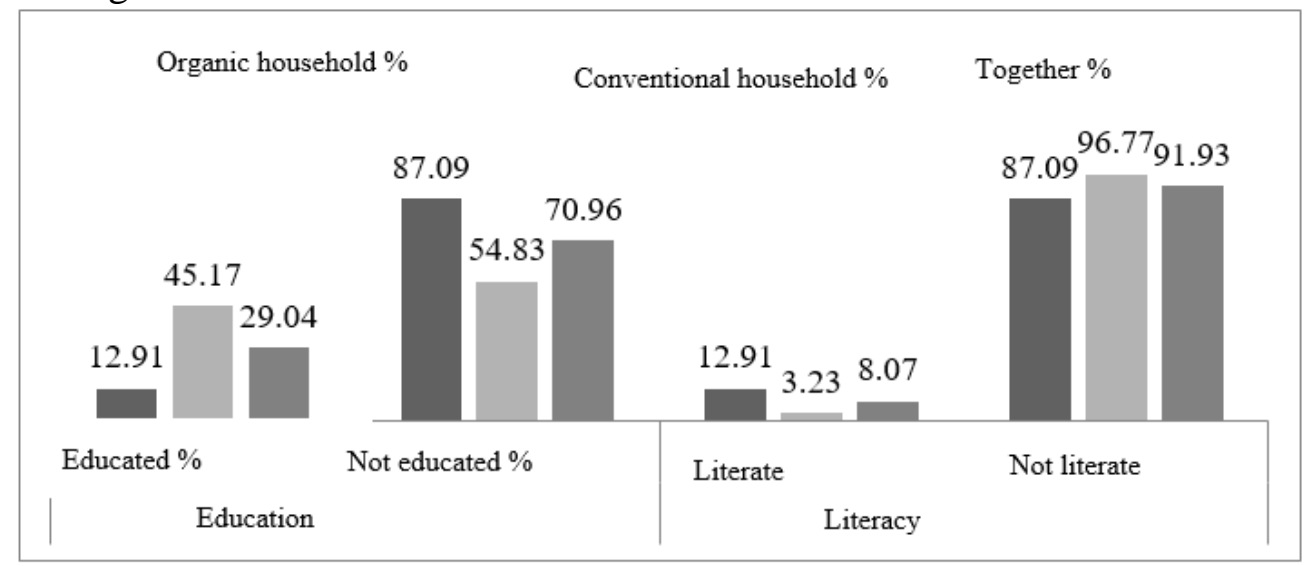

Figure 2: Percentages of educated and literate according to the types of cotton

\section{Household size and number of agricultural workers}

Table 2 indicates that the households of conventional and organic systems have an average size of $6.54( \pm 3.47)$ and $7.48( \pm 5.47)$ people respectively. The average number of agricultural workers is higher among organic households (or 4,032 workers). In addition, farmers in the organic 
system receive more visits from extension agents than those in the conventional system. This response to government efforts to protect the environment and ensure the health of agricultural farmers.

Table 2: Characteristics of the households surveyed from the two farming systems

\begin{tabular}{|l|l|l|}
\hline Characteristics & Conventional system & Organic system \\
\hline Age & $40,00(12,182)^{* *}$ & $43,80(13,257) * *$ \\
\hline Educational level & $2,35(2,98)^{* * *}$ & $0,774(2,15)^{* * *}$ \\
\hline Household size & $6,548(3,472)$ & $7,484(5,476)$ \\
\hline Number of agricultural workers & $3,806(2,040)$ & $4,032(2,858)$ \\
\hline Experience in cotton farming & $9,968(5,128) * *$ & $6,226(3,127)^{* *}$ \\
\hline $\begin{array}{l}\text { Experience in organic cotton } \\
\text { farming }\end{array}$ & 0 & $4,613(1,283)$ \\
\hline Field-house distance & $4,47(2,74)^{* * * *}$ & $2,27(1,72)^{* * * *}$ \\
\hline Available acreage & $5,82(2,57)^{*}$ & $3,86(3,51)^{*}$ \\
\hline Cultivated acreage & $4,86(2,94)^{* *}$ & $3,11(2,72)^{* *}$ \\
\hline Cotton acreage & $2,14(1,31)^{* *}$ & $1,38(1,282)^{* *}$ \\
\hline Prosperity classes & Conventional system $(\%)$ & Organic system $(\%)$ \\
\hline Very poor & 15 & 15 \\
\hline Poor & 15 & 20 \\
\hline Rich & 40 & 32,50 \\
\hline Prosperous & 30 & 32,50 \\
\hline
\end{tabular}

Source: SyproBio Survey, 2014, () = Standard deviation; ** = Significant difference at the threshold $5 \%, * * *=$ significant at the threshold of $1 \%, *=$ significant at the threshold of $10 \%$.

\section{Distance between cotton fields and houses, total available acreages, and the acreages of cotton cultivated}

Conventional households sow more acreages than organic ones.

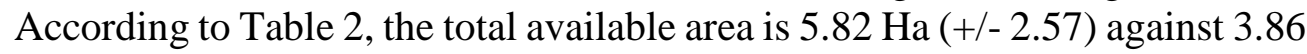
$\mathrm{Ha}(+/-3.97)$ for organic, with a significant difference at the $10 \%$ threshold. In addition, the total cultivated acreage is respectively $4.86 \mathrm{Ha}(+/-2.94)$ and $3.11 \mathrm{Ha}(+/-2.72)$ for the conventional and organic system with the cultivated acreage of cotton which represents almost half. The difference between the acreages of the systems is significant at the 5\% threshold. The distance between the cotton field and the house is greater in the conventional system $(4.47 \mathrm{~km})$ than the organic $(2.27 \mathrm{~km})$ with a significant difference at a threshold of $1 \%$.

\section{The level of the prosperity of the households surveyed by the systems}

The classification of households surveyed by the qualitative method of Barbara Grandin (Grandin, 1988), shows that 32.5\% of households in the organic system are prosperous against $30 \%$ for the conventional. On the other hand, $35 \%$ of organic households are at the poorest against $30 \%$ for conventional. 


\section{Analysis of farming costs for organic and conventional farms}

The results of the study show that households in the conventional system spend a lot on the acquisition of chemical inputs (fertilizers, pesticides, and herbicides) than organic farms which use organic inputs (compost, biopesticides) (Table 3). The conventional farms have the higher variable costs which are around 250,000 FCFA per average cultivated area of the conventional system and 54,000 FCFA for organic with a significant difference at the $1 \%$ threshold. This is explained by the fact that the average costs of the purchase of seeds, fertilizers, and pesticides, are significantly higher than those of organic farms with a significant difference threshold of $1 \%$ (Table 3). Organic farms make much more use of family labor in their farming activity and therefore minimize variable farming costs.

Tableau 3: Comparison of the variable farming costs of both conventional and organic systems.

\begin{tabular}{|l|l|l|l|l|}
\hline Costs & systems & Means & $\begin{array}{l}\text { Standard- } \\
\text { deviation }\end{array}$ & Student t test \\
\hline \multirow{2}{*}{ Fertilizer } & conventional & 106120,96 & 92414,31 & $4,693 * * *$ \\
\cline { 2 - 4 } & organic & 16229,98 & 25127,72 & \\
\hline \multirow{4}{*}{ Pesticide } & conventional & 37216,94 & 141775,83 & $4,502 * * *$ \\
\cline { 2 - 4 } $\begin{array}{l}\text { Salaried } \\
\text { workforce }\end{array}$ & organic & 4782,42 & 4147,66 & \\
\hline \multirow{3}{*}{ Seed } & conventional & 37654,17 & 29828,43 & \multirow{2}{*}{1,377} \\
\cline { 2 - 4 } & organic & 23891,73 & 21909,08 & \\
\hline Variables costs & conventional & 10670,26 & 9801,91 & \multirow{2}{*}{$4,816^{* * *}$} \\
\cline { 2 - 4 } & organic & 6041,07 & 4555,04 & \multirow{2}{*}{$4,586^{* * *}$} \\
\cline { 2 - 4 } & conventional & 246101,00 & 193890,57 & \\
\hline
\end{tabular}

Source: SyproBio survey, 2014, () = Standard deviation; $* * *=$ Significant (threshold 1\%).

\section{Analysis of gross income and gross margin of different crops produced in two types of system}

Table 4 shows that all crops in rotation with cotton have a positive average gross margin. This means that the crops are economically profitable regardless of the conventional or organic system. In comparison, cowpea offers a higher gross margin in the conventional system with a gross margin of around 98,877 FCFA / ha versus 96,870 FCFA/ha in the organic system. The same results were found for maize farming gross margin, which is 197069 FCFA / ha for the conventional system and 146061 FCFA / ha for the organic system. Unlike cowpeas and maize, other crops such as cotton and soybeans offer higher gross margins in the organic system. In addition, organic cotton farming is more profitable than conventional cotton farming (99,923 FCFA / ha against 76,297 FCFA). This is related to farming costs (variable costs) which are lower in the organic system. 
Regarding the gross income, the analysis of Table 4 shows that the gross income is positive for both the organic and the conventional systems. This gross income is higher for the organic household $(104,464$ (+/- 162,977) FCFA / Ha than for the conventional household $(115,441$ (+/- 89,602) FCFA / Ha). The student's t-test reveals that the difference between the average gross income of organic farms and that of conventional farms is significant at the $10 \%$ threshold. This trend is normal because the gross margins of crops in the system are higher in the organic system. It has been noted that farmers in organic systems do not use large areas for cultivation: an average of two (2) hectares for farmers in organic systems compared to 9 hectares on average for farmers in conventional systems.

Table 4: Gross margins and gross incomes of rotation crops of a conventional and organic system

\begin{tabular}{|c|c|c|c|}
\hline Cultures & Types of operations & $\begin{array}{l}\text { Average gross margin } \\
\text { (FCFA/ha) }\end{array}$ & Test t \\
\hline \multirow[t]{2}{*}{ Cotton } & Conventional & $76297(62127)$ & \multirow[t]{2}{*}{$-1,71 *$} \\
\hline & Organic & $99923(57788)$ & \\
\hline \multirow[b]{2}{*}{ Corn } & Conventional & $197069(408528)$ & \multirow[t]{2}{*}{$1,254 *$} \\
\hline & Organic & $146061(112199)$ & \\
\hline \multirow[b]{2}{*}{ Sorghum } & Conventional & $136772(114661)$ & \multirow[t]{2}{*}{0,539} \\
\hline & Organic & $150662(106868)$ & \\
\hline \multirow[b]{2}{*}{ Soy } & Conventional & $165335(124374)$ & \multirow[t]{2}{*}{$0,648^{*}$} \\
\hline & Organic & $192820(143143)$ & \\
\hline \multirow{3}{*}{ Cowpea } & Conventional & $98877(95583)$ & \multirow[t]{2}{*}{0,149} \\
\hline & Organic & $96870(74075)$ & \\
\hline & Types of operations & Gross income & Test t \\
\hline \multicolumn{3}{|c|}{ Gross income from both systems (FCFA/ha) } & \\
\hline \multirow{2}{*}{$\begin{array}{l}\text { Gross income from } \\
\text { systems (FCFA / Ha) }\end{array}$} & Conventional & $104464(162977)$ & \multirow[t]{2}{*}{$1,877 *$} \\
\hline & Organic & $115441(89602)$ & \\
\hline
\end{tabular}

Source: SyproBio Survey, $2014 ;($ )=Ecart-type $; * * *=$ Significative (seuil 1\%); $* *=$ Significative (seuil 5\%); * $=$ Significative (seuil 10\%).

\section{Determinants of agricultural income from organic and conventional farms}

The analysis of Table 5 shows that the regression models estimated for the determination of the factors that influence the agricultural income of the organic and conventional farming systems in the commune of Tanguiéta are valid and significant at the $1 \%$ level (Prob $>\mathrm{F}=0.0015$ for the organic against Prob $>F=0.0001$ for the conventional). The adjusted $R^{2}$ obtained from the regression models for the organic and conventional system are 0.4485 and 0.5004 , respectively. Thus, the variation of the variables introduced into the models explains respectively $44.85 \%$ of the variation of the dependent 
variable "agricultural gross income of the organic system" and $50.04 \%$ of the variation of the dependent variable "agricultural gross income of the conventional system". Table 5 highlights the determinants of the agricultural income of the organic system, which are: the level of prosperity of the household, possession of secondary activity, the size of the household, the agricultural asset, the contact with the extension, the cotton acreage, the total acreage available and experience in organic cotton farming. The determinants of the agricultural income (gross income) of the conventional system are household prosperity level, distance from home to the cotton farm, and the gender of the farm manager.

Table 5: The estimate of the model for identifying the determinants of agricultural income from organic and conventional farms

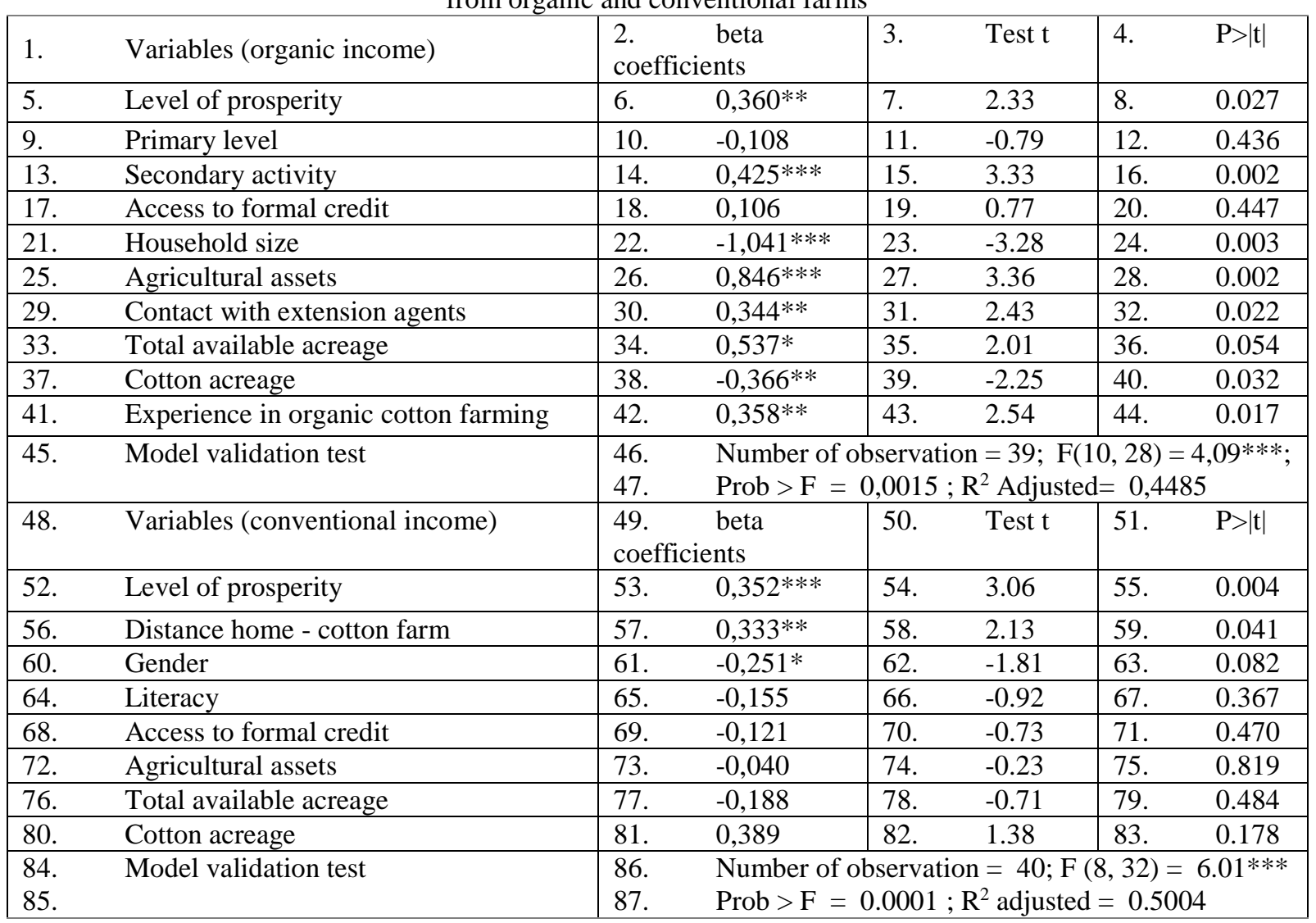

Source: SyproBio survey, 2014; *** = Significant (threshold 1\%); ** = Significant (threshold 5\%); * =Significant (threshold 10\%); dependent variable= gross income of the conventionnal and organic farming systems.

Indeed, the variable "the level of prosperity of the head of household" has a positive and significant effect at the respective thresholds of 5\% and 1\% on the agricultural income of organic and conventional systems. This means that the increase in the level of prosperity of the head of the household leads 
to a rise in the agricultural gross income of the households for both types of systems. This can be explained by the fact that a prosperous household has the financial means to meet the costs of agricultural farming and to be rational.

The variable "Possession of secondary activity" has a positive and significant influence at the $1 \%$ threshold on the agricultural gross income of the household in the organic system. This means that when a head of household has a secondary activity, his agricultural gross income increases. This could be explained by the fact that secondary activity generates income which increases the overall household income and therefore the household's productive resources. Thus the farmer can easily invest in the factors of farming (labor, inputs, etc.).

The variables "Household size" and "Cotton acreage" have negative and significant effects on the agricultural gross income of the household of the organic system at the thresholds of $1 \%$ and $5 \%$, respectively. Thus, when these variables increase by $1 \%$, agricultural income decreases by 1.041 and 0.366 respectively. This can be explained by the fact that very few members of the household are agricultural workers, and therefore do not contribute to fieldwork. This confirms the positive effect of the variable "agricultural assets" on the agricultural gross income of the household of the organic system at the $1 \%$ threshold. So when the household's farm assets grow by $1 \%$, gross income increases by 0.846 . This is because assets contribute to agricultural activities in order to reduce labor costs. On the other hand, the negative sign of the cotton acreage in an organic system can be explained by the fact that the activities of cotton farming are difficult and require a lot of care from the farmers. Thus, an increase in its acreage would generate additional costs and labor, which can be difficult to cover and which can decrease farms' income. However, the variable "total available acreage" has a positive and significant effect at the $10 \%$ threshold on the agricultural income of households in the organic system. So when the available land area of the household increases by $1 \%$, agricultural income increases by 0.537 . This can be explained by the fact that the available area allows farmers to practice crop rotation and fallow techniques in order to maintain and improve the level of soil fertility which has a positive effect on crop yields.

The variables "Experience in organic cotton farming" and "Contact with extension agents" positively and significantly influence the agricultural income of organic households at the 5\% level. This means that when these variables increase by $1 \%$, farm income also increases. This increase in income is 0.358 for the variable experience in the organic system. These influences can be explained by the fact that experience allows farmers to use these acquired skills to make their operations profitable, while the contact with extension agents allows them to acquire training on new farming practices in order to minimize risks and improve their returns. 
In addition, the variable "Gender = man" has a negative and significant effect at the $10 \%$ threshold on the agricultural income of households in the conventional system. This means that when the head of the household is a woman, agricultural income increases. This is explained by the fact that women only cultivate small areas which maintain it well.

Distance from home to cotton farms has a positive and significant effect at the 5\% threshold on the agricultural income of households in the conventional system.

\section{Discussion}

Organic farming is an activity that attracts women farmers of Benin and helps to resolve the inequality between men and women in terms of access to land. The study shows a large proportion of women in the organic system because women in this system have the possibility of having their own fields to practice agriculture. This result is consistent with the research results of (Sodjinou et al., 2015); but it is not consistent with those of (Elepu \& Ekere, 2009) which show that there are more women in conventional agriculture. This difference is explained by the socio-economic realities of each country and by the policies for the advancement of women in various countries.

The socio-demographic characteristics show that farmers who practice organic farming are older than those of conventional farming. This is consistent with the results of (Krause \& Machek, 2018), and is explained by the fact that older people have more experience in agriculture and understand that it is important to adopt organic farming to protect their environment and their health while young farmers ignore or trivialize the disadvantages of conventional agriculture.

The results of the study demonstrate once again that organic farming is more profitable than conventional farming (Elepu \& Ekere, 2009; Tovignan et al., 2018), and this despite the constraints encountered by agricultural farmers of the organic system. The economic advantage of the organic system is related to the farming costs of organic farming, which are lower than those of conventional farming. Farmers who adopt the conventional system bring in enough items such as chemical fertilizers, pesticides, labors. These elements increase farming costs and give a comparative advantage to the organic system (Eyhorn et al., 2011; Forster et al., 2013).

Crops rotated with cotton show an advantage to both corn and soybean crops. These results are consistent with those of (Eyhorn et al., 2011; Forster et al., 2013) who showed an economic benefit when corn and soybean crops are rotated with cotton. These results also confirm the study by (Adjiba et al., 2019) which showed that the net margin for organic corn is positive and higher in the organic system. Indeed, these authors demonstrate that corn and soybean crops in an organic system are more profitable in organic systems. The 
explanations can be summed up in that organic farming uses less labor and this favors the two other crops (corn and soybean).

The conventional households display the highest cultivated areas. Organic cotton farmers are therefore small farmers in terms of the total area cultivated compared to those producing conventional cotton. They find it difficult to spread, for example, organic fertilizers over large areas and to carry out phytosanitary treatments easily on a large scale.

Regarding the factors that influence the economic performance of organic and conventional systems, some of the determinants found corroborate with the factors found by (Hountondji et al., 2018) who revealed that factors such as possession of secondary activity, the distance between home and farm, total cultivated area, contact with extension agents, level of fertility, size of livestock and crop rotation with legumes are the determinants of the economic efficiency of organic cotton farming in northern Benin. Some of these factors are also confirmed by the study of (Tovignan et al., 2018) who analyzed the determinants of the profitability of organic cotton in the North and Center of Benin. In addition, the study of Bonou-zin (2012) in the same areas found that the level of soil fertility, access to credit, gender, and the level of education of the farmers positively influence the efficiency of organic cotton technique.

\section{Conclusion}

Organic farms have a positive income which shows that they are economically profitable. They also produce with a lower farming cost than farmers of a conventional system. As a result, they have better economic performance than conventional ones. In addition, with the application of organic premiums on food crop prices, the gross income of organic farms will be better than that of conventional farms. Despite the many constraints encountered by organic growers, the activity is more profitable than conventional agriculture regardless of the angle of analysis considered. But much remains to be done in the field of organic agriculture, as the areas shown for organic farming are still low, and to ensure food security, strategies for large-scale farming should be found. In addition to the problems of areas allocated to this agriculture, it is necessary to continue with awareness campaigns so that viable crops (that is to say that give positive gross margins in association with cotton in organic farming) are promoted (corn and soy). Thus, the determinants of the agricultural income of the organic system are the level of prosperity of the household, possession of secondary activity, the size of the household, the agricultural assets, the contact with the extension, the cultivated area of cotton, the total available area, and experience in organic cotton farming. The determinants of the agricultural income in the conventional system are the level of prosperity of the household, the distance between the house and the cotton farm, and the gender of the farm manager. 
However, it would then be necessary to continue and intensify programs to disseminate best organic farming practices to farmers while taking into account the factors identified.

Author Contributions: All authors contributed equally to this article; they have read and agreed to the published version.

Funding: The authors gratefully acknowledge the financial support received from the SyproBio institute in 2014.

Conflicts of Interest: The authors declare no conflicts of interest.

\section{References:}

1. Adjiba, C., S, T., Hountondji, S., P., Tovignan, D. S., Kirabe, G., B, A., \& Yabi, J. A. (2019). Analyse comparative des performances économiques de la production du maïs dans les exploitations conventionnelle et biologique au nord et centre du Bénin-Slire. http://www.slire.net/document/2529

2. Brookes, G., \& Barfoot, P. (2012). The income and production effects of biotech crops globally 1996-2010. https://www.tandfonline.com/doi/full/10.4161/gmcr.20097

3. Danus, P. (2020). Un outil d'aide à la décision au service de l'agroécologie: Les pratiques de conservation et de fertilisation du sol appliquées au village de Kotopounga dans la commune de Natitingou au Bénin. https://matheo.uliege.be/handle/2268.2/10038

4. Degla, K., P. (2012). Rentabilité économique et financière des exploitations cotonnières basées sur la Gestion Intégrée de la Fertilité des Sols et des Ravageurs au Nord-Bénin-Slire.

5. http://www.slire.net/document/1746

6. Dossa, F., Todota, C., Miassi, Y., \& Abdel-Aziz, A. (2018). Analyse comparée de la performance économique des cultures de coton et de maïs au Nord-Bénin: Cas de la commune de Kandi. International Journal of Current Advanced Research, 1, 118-130.

7. Echaudemaison, C., D., Soin, R., Joubert-Mellet, G., Leblanc, O., Bazureau, F., Chartoire, R., Faugere, J.-P., Bosc, S., \& Cendron, J.-P. (2017). Dictionnaire d'économie et de sciences sociales | Dictionnaires thématiques |Éditions NATHAN.

https://www.nathan.fr/catalogue/fiche-

produit.asp?ean13=9782091503110

8. Elepu, G., \& Ekere, W. (2009). Competitiveness of Cotton in Organic and Conventional Production Systems in Uganda. 
9. Eyhorn, F., Mahesh, R., \& Mäder, P. (2011). The viability of cottonbased organic farming systems in India: International Journal of Agricultural Sustainability: Vol 5, No 1.

https://www.tandfonline.com/doi/abs/10.1080/14735903.2007.96848 11

10. Finger, R., El Benni, N., Kaphengst, T., Evans, C., Herbert, S., Lehmann, B., Morse, S., \& Stupak, N. (2011). A Meta Analysis on Farm-Level Costs and Benefits of GM Crops. Sustainability, 3(5), 743-762. https://doi.org/10.3390/su3050743

11. Forster, D., Andres, C., Verma, R., Zundel, C., Messmer, M., \& Mâder, P. (2013). Eprints biologiques-Rentabilité économique des systèmes de production à base de coton biologique par rapport aux systèmes de production conventionnels à base de coton dans un essai sur le terrain à long terme en Inde. https://orgprints.org/24836/

12. Gbede, R., T., Biaou, P., D., kinkpe, T., A., \& Yabi, J. (2018). Performances technico-économiques comparées des systèmes traditionnel et moderne d'étuvage du riz dans les communes de Gogounou et Banikoara au Nord-Bénin. 8, 103-114.

13. Grandin, B. (1988). Wealth Ranking in Smallholder Communities : A Field Manual. Practical Action Publishing.

14. Grüning, M. (2002). Performance-Measurement-Systeme : Messung und Steuerung von Unternehmensleistung. Deutscher Universitätsverlag. https://doi.org/10.1007/978-3-663-08089-3

15. Hermann, M. B., Moumouni, I., \& Tokore Orou Mere, S. B. J. (2016). Contribution à l'amélioration des pratiques paysannes de production durable de coton (Gossypium hirsutum) au Bénin : Cas de la commune de Banikoara. International Journal of Biological and Chemical Sciences, 9(5), 2401. https://doi.org/10.4314/ijbcs.v9i5.12

16. Houndekon, V. (2013). Analyse des systèmes de production du coton biologique et du coton conventionnel au Bénin.

17. Hountondji, S. P., Tovignan, D. S., \& Sodjinou, E. (2018). Analyse de l'efficacité économique de la production du coton biologique équitable au Bénin Analysis of the economic efficiency of organic cotton production in Benin. 27-38.

18. Krause, J., \& Machek, O. (2018). A comparative analysis of organic and conventional farmers in the Czech Republic. Agricultural Economics, 64 (2018)(No. 1), 1-8. https://doi.org/10.17221/161/2016AGRICECON

19. Matthess, A., Akker, E., Van Den, Chougourou, D., \& Midingoyi, S. (2005). Compétitivité et durabilité de cinq systèmes culturels cotonniers dans le cadre de la filière. 
https://www.researchgate.net/publication/259998982_Competitivite_ et_durabilite_de_cinq_systemes_culturaux_cotonniers_dans_le_cadre _de_la_filiere

20. OBEPAB. (2002). Le Coton au Bénin: Rapport de consultation sur le coton conventionnel et le coton biologique au Bénin-Slire. http://www.slire.net/document/1371

21. OCDE. (2005). Moderniser l'État-OCDE. https://www.oecd.org/fr/gov/moderniserletat.htm

22. Paraïso, A., Yabi, J., SOSSOU, A., Wallis, N., \& Yegbemey, R. (2012). Rentabilité économique et financière de la production cotonnière a ouaké au Nord-ouest du Bénin. Ann. Sc. Agro., ISSN 1659-5009, 16, 91-105.

23. Sodjinou, E., Glin, L. C., Gyan, N., Tovignan, D. S., \& Hinvi, J. (2015). Socioeconomic determinants of organic cotton adoption in Benin, West Africa | SpringerLink. https://link.springer.com/article/10.1186/s40100-015-0030-9

24. Sonnentag, S., \& Frese, M. (2002). Performance Concepts and Performance Theory. In Psychological Management of Individual Performance (p. 1-25). John Wiley \& Sons, Ltd. https://doi.org/10.1002/0470013419.ch1

25. Ton, P., \& Wankpo, E. (2004). Projet d'analyse d'une spéculation agricole par pays, financé par le programme «Renforcement des capacités commerciales » de la F.I.P.A.(Fédération Internationale des Producteurs Agricoles). 56.

26. Tovignan, D. S., Sodjinou, E., Glin, L. C., Hinvi, J., Bonou-zin Dossi, C. R., Koussahoué, S., \& Nicolay, G. L. (2018). Analyse des déterminants de la rentabilité du coton biologique et conventionnel au Bénin (Journal Paper $\mathrm{N}^{\circ} 1$ ). International Journal of Innovation and Scientific Research. https://orgprints.org/34703/

27. Vognan, G., Glin, L., Bamba, I., Ouattara, B. M., \& Nicolay, G. (2017). Analyse comparative de la rentabilité des systèmes de production de coton biologique, conventionnel et transgénique au Burkina Faso. 13. 